\title{
Using Context Clues in Determining Contextual Meaning of Arabic Words
}

\author{
Mohd Azidan Abdul Jabar* and Syazmira Mansor \\ Department of Foreign Languages, Faculty of Modern Languages and Communication, Universiti Putra \\ Malaysia, 43400 Serdang, Selangor, Malaysia
}

\begin{abstract}
Language context plays an important role in determining the meaning of a word. To understand its meaning, it is imperative that context be considered. Today, many students have difficulty understanding the meaning of Arabic words as they are unable to understand the context. However, words, phrases or sentences in a text can serve as a guide or clue to understand the meaning of unknown words. This is termed as context clues. This study aims to identify how context clues help students determine the contextual meaning of an Arabic word. Their understanding process is analysed from the critical discourse analysis perspective using a three-dimensional model introduced by Fairclough (1989). This study was conducted using a questionnaire and interviews with twenty undergraduates studying Arabic language from five Malaysian universities. Five Arabic words were selected from five news texts quoted from the Arab news portal al-Ra'i (http://alrai.com/); covering sports, economics, politics, social and technology. The words selected have many meanings,

ARTICLE INFO

Article history:

Received: 10 January 2021

Accepted: 29 March 2021

Published: 30 June 2021

DOI: https://doi.org/10.47836/pjssh.29.2.31

E-mail addresses:

azid@upm.edu.my (Mohd Azidan Abdul Jabar)

syazmiramansor@gmail.com (Syazmira Mansor)

*Corresponding author depending on the context of the sentence. Students must determine the meaning contextually by stating the context clues in the text that guided them. The findings show that context clues can help students understand the meaning of Arabic words and enhance their understanding based on its sentence context.

Keywords: Arabic language, context clues, contextual, three-dimensional model, word meanings
\end{abstract}




\section{INTRODUCTION}

The meaning of a word in a text or discourse cannot be obtained lexically or merely by one meaning but needs to take into consideration its contextual features (Abdul Jabar, 2011). Understanding the meaning of vocabulary based on a linguistic context means that a word has its meaning understood in the context of a sentence and in the grammatical structure based on the rules and principles of grammar (Requejo, 2007) or the connection of meaning with other words (Benjamin $\&$ Crow, 2009). According to the views of the anthropologist, Hall (1974), relating to context, he stresses that "information taken out of context is meaningless and cannot reliably interpreted" (p. 21). This statement shows that in speech or text there are three main aspects that must be present: information, context, and meaning.

When faced with a text or discourse, at least $98 \%$ of the total words in the text should be read for the purposes of understanding (Carver, 1994; Hsueh-chao \& Nation, 2000). Difficulties understanding the message and important content will arise if there are many unknown words. Understanding the meaning of a word can also be achieved using the contextual clue found in a text. This can refer to any word, term, phrase or sentence found in the text from the perspective of structure, grammar or syntax. Harris and Hodges (1995) define contextual clue as the reading strategy used to determine the meaning of an unknown word by obtaining assistance from words, phrases, sentences or illustrations that provide an idea directly or indirectly about the meaning of that word. It may be more effective for the reader to start with the process of using the contextual clue to identify a word as it is then easier to build the meaning of the word (Allen, 1998). Contextual clue can also help create interaction between the reader and the text which can help support the process of determining the meaning of the unknown word (Hibbard, 2009). Hence, information that provides the real meaning, or words in sentences is known as context clue (Mansor \& Abdul Jabar, 2019).

Learning Arabic language has a long history in Malaysia, however, according to research the level of language skill among students is still unsatisfactory (Baharum $\&$ Samah, 2015). Students who pursue the Arabic language course in the institutions of higher learning especially non-native speakers are observed to experience difficulties in commanding the language. Their weakness in understanding the Arabic language vocabulary is worrying (Hasmam et al., 2017).

Educators should also emphasise the contextual feature in understanding the meaning of vocabulary. In linguistics, context plays an imperative role in clarifying the true meaning of a word. Sometimes the context cannot be seen clearly and obviously, as it is hidden between the words and vocabulary found in the text (Dash, 2008). Hence, one has to read the entire text when faced with many unknown words. One can then deduce the meaning of the word based on the correct and accurate context of the sentence. 
To resolve the problem which exists in the study of languages, especially the Arabic language, we view that one of the alternatives is applying the use of contextual clues in determining the contextual meaning of an Arabic word. Hibbard (2009) opines that one of the effective techniques to aid the process of understanding the meaning of difficult vocabulary is based on the clue or guide found in the context of the sentence. The information which supplies the meaning of the word is known as the context clue. This context clue can consist of one or more words, phrases, declarative sentences, definitions, synonyms, antonyms and others. Hasmam (2012) is of the view that the strategy of understanding the meaning of vocabulary by way of context clue is especially important and should be given the appropriate emphasis.

Context clue also enables increased knowledge regarding the meaning of new words through reading. This was supported by the research findings by Yuen (2009) which show that the use of context clue is able to improve understanding the meaning of new words while reading a text or discourse. Mahmoud (2016) also conducted research on how context clue can help in the reading process of students undertaking the English as a Foreign Language (EFL) course. The findings indicate that the students show a gradual improvement in using context clue and giving clearer meaning to unknown words.

\section{Objectives}

The main objective of this study is to identify the role of context clues in determining the contextual meaning of Arabic words among students. More specifically, the study sought to:

1. Identify the contextual meaning of Arabic words that students understand from their context clues.

2. Analyse the linguistic processes involved in understanding the contextual meaning of Arabic words based on Fairclough's three-dimensional model.

\section{METHODOLOGY}

This research is in the form of a qualitative research conducted using the field study method. This study involved 20 undergraduate students majoring in Arabic language in 5 Malaysian universities: Universiti Putra Malaysia (UPM), The National University of Malaysia (UKM), Islamic Science University of Malaysia (USIM), University of Malaya (UM) and Universiti Teknologi Mara (UiTM) Shah Alam. The findings were analysed using descriptive analysis to explain the use of context clue in determining the meaning of the Arabic word by the student. A model from the critical discourse analysis field was applied in this research; the threedimensional model pioneered by Fairclough (1989), which connects the text or discourse with the social process experienced by the reader.

\section{Research Data}

Research data was obtained from a questionnaire and interviews of respondents conducted in the Malay language. In conducting this study, we also collected 
research data from books, journals and theses. Five Arabic news texts were taken from an Arabic online news portal, al-Ra'i (http://alrai.com). Part of the rationale for choosing this news portal is that it uses the fusha or standard Arabic language, which is easily understood by various levels of society. This news portal also presents various local and international current issues.

To simplify the analysis process, the coding method was used. The five Arabic words selected and tested were labelled with the code "P". The code " $R$ " was used for the respondents.

\section{Research Theory}

The research of discourse analysis based on this context clue uses the three-dimensional model framework introduced by Fairclough (1989). This model views text based on three dimensions, which are text, discourse practice and social practice.
The first dimension is text, which is analysed linguistically by looking at the vocabulary, sentence, and semantic features. Fairclough also observed cohesion and coherence, how the word or sentence is combined to form a meaning. The second dimension, which is discourse practice, is connected to the production and consumption of text used to analyse the process of the text's production and interpretation by the reader. Fairclough explained that the interpretation procedure is divided into two parts which are interpretation of text and context. The third dimension is called social practice which is the dimension that connects the first and second dimensions with the process experienced by the recipient of the text. This dimension proves that the discourse is part of social practice.

The three dimensions developed by Fairclough can be depicted in Figure 1.

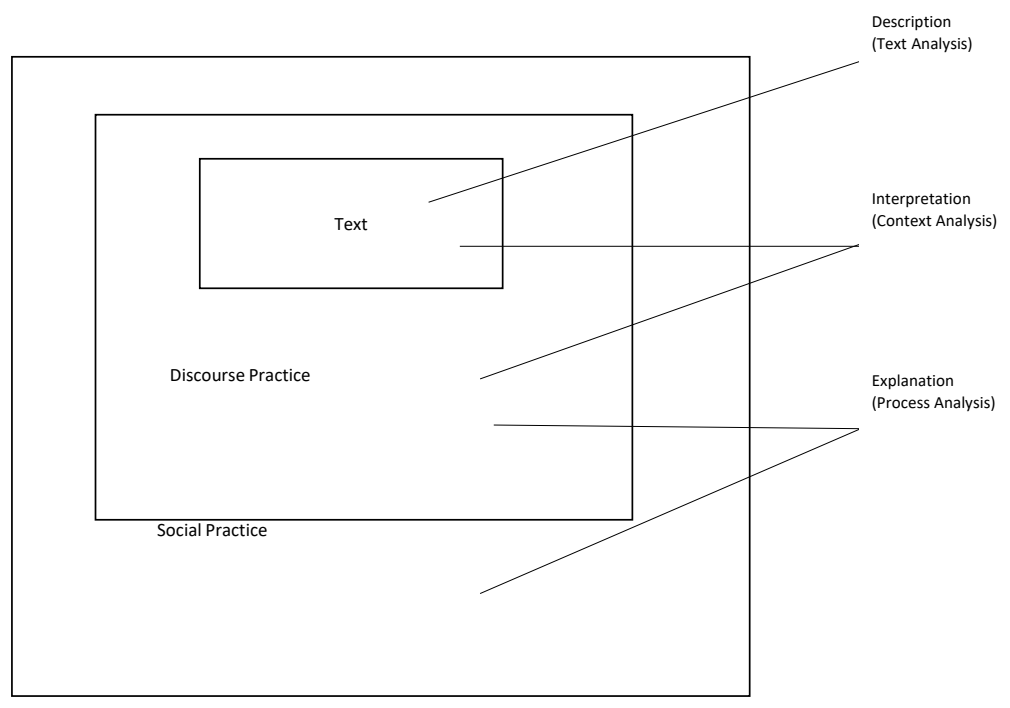

Figure 1. Fairclough's Three-Dimensional Model (1989) 


\section{RESULTS AND DISCUSSION}

The analysis of the research data will discuss the results obtained from 20 respondents regarding the process of determining the meaning of the Arabic word based on context clues. The findings will be explained using the Fairclough three-dimensional model framework. We will explain the textual and discourse practice dimensions relating to the determination of the meaning of the word contextually based on the context clue. In the social practice dimension, we will explain the process the student underwent to determine the context clue and the meaning of the word tested.

\section{Analysis of Textual Dimension}

This first dimension focuses on the linguistic features found in a discourse or text. Here, we will only focus on the semantics feature which is the meaning of the word determined contextually by the respondent based on the word tested. Five Arabic words change meaning when placed in a different context of sentences. The respondent answers have been classified and shown in Table 1.

Based on the answers for P1, most respondents were able to provide the accurate meaning which is "gol" [goal] as interpreted by R10, R18, R19 and R20. Whereas R01, R03, R04 and R05 added the word "menjaringkan" [scored], a verb usually paired with the word "gol" in football terminology. Some respondents R02, R06, R07, R08, R09, R11, R12, R13, R14 and R15 explained "هَدَنَت" using the original meaning which is "tujuan" [purpose] or "matlamat" [objective]. That meaning can also be applied, as "gol" becomes the objective or main purpose to win a football match. R16 and R17 gave the meaning "sasaran" [target] and "target" that can also be referred to as "goal" in this context although not exact in the context of the actual sentence as the word "هَدَفتَ" "

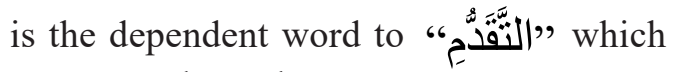
means "early goal".

The contextual meaning for P2 varied. Most respondents gave the meaning "dedah" [expose] with different prefixes and suffixes. The word "dedah" in the original text means "open" and "uncovered". R01, R03, R14 and R15 gave the meaning "pendedahan" [exposure] whereas R02, R04, R05, R06, R07, R08, R13, R18 and R20 defined "تَعَرََّضنَ"as “terdedah” [exposed]. One respondent, R10, gave the meaning in English, "exposure". All these are accurate based on the context of the sentence in the actual text. Some respondents gave different but almost similar meaning to "dedah" such as "paparan" [display] as given by R09 and R12 whereas R16 gave "memaparkan" [displays]. According to Kamus Dewan (2005), both these meanings have the meaning mempamerkan [to display] or mendedahkan [to expose] something so that it can be seen. Another contextual meaning given by R17 was "dipamerkan" [on display] which means showing something to the public. However, this word is mostly used for competition or demonstration. R19 defined "تَعَرَّضَ" as "terpampang" [clearly seen] which means the same as displays. Another respondent, R11, gave a different meaning from the others, which is "tersebar" [distributed]. 
Mohd Azidan Abdul Jabar and Syazmira Mansor

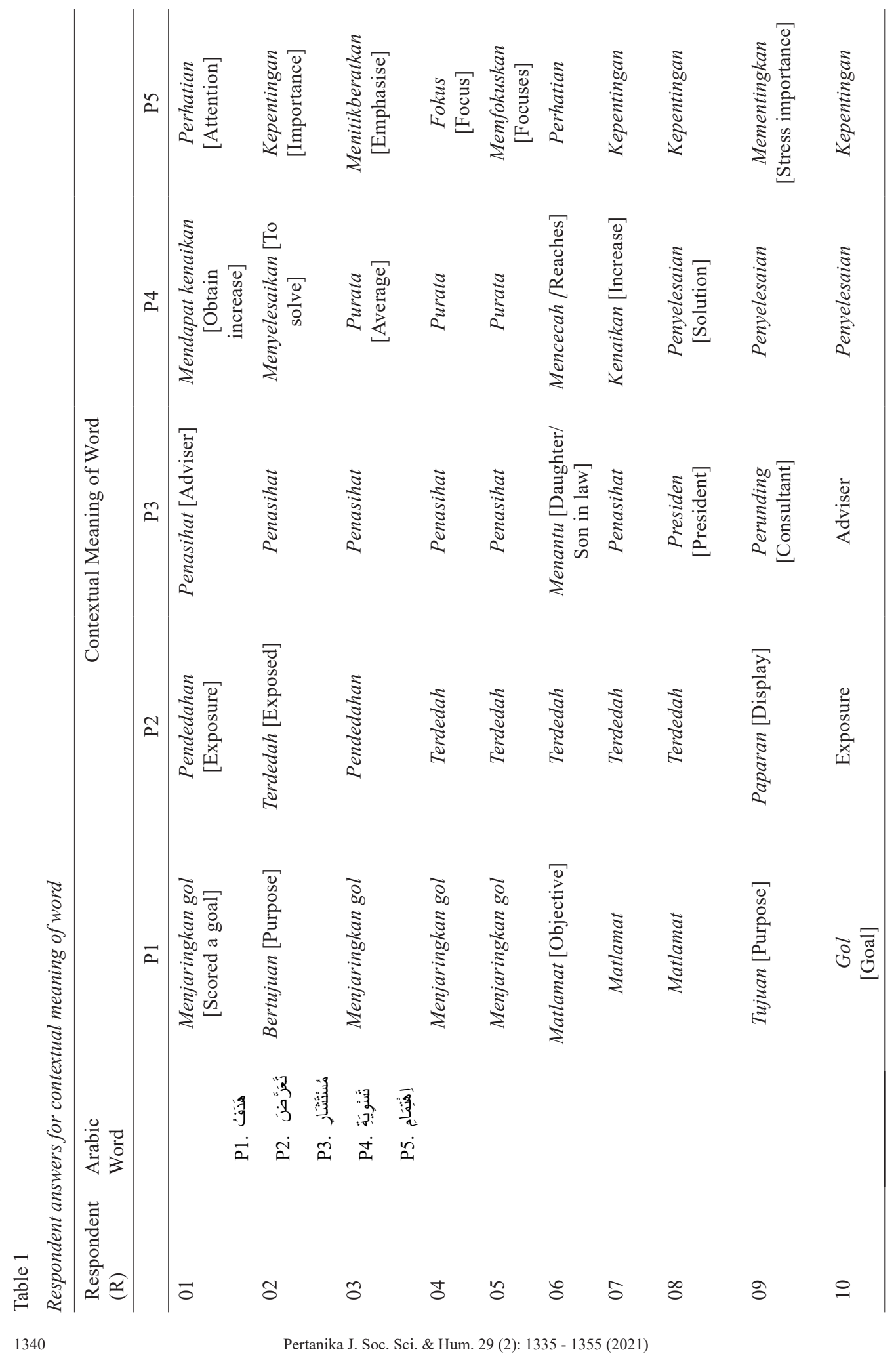




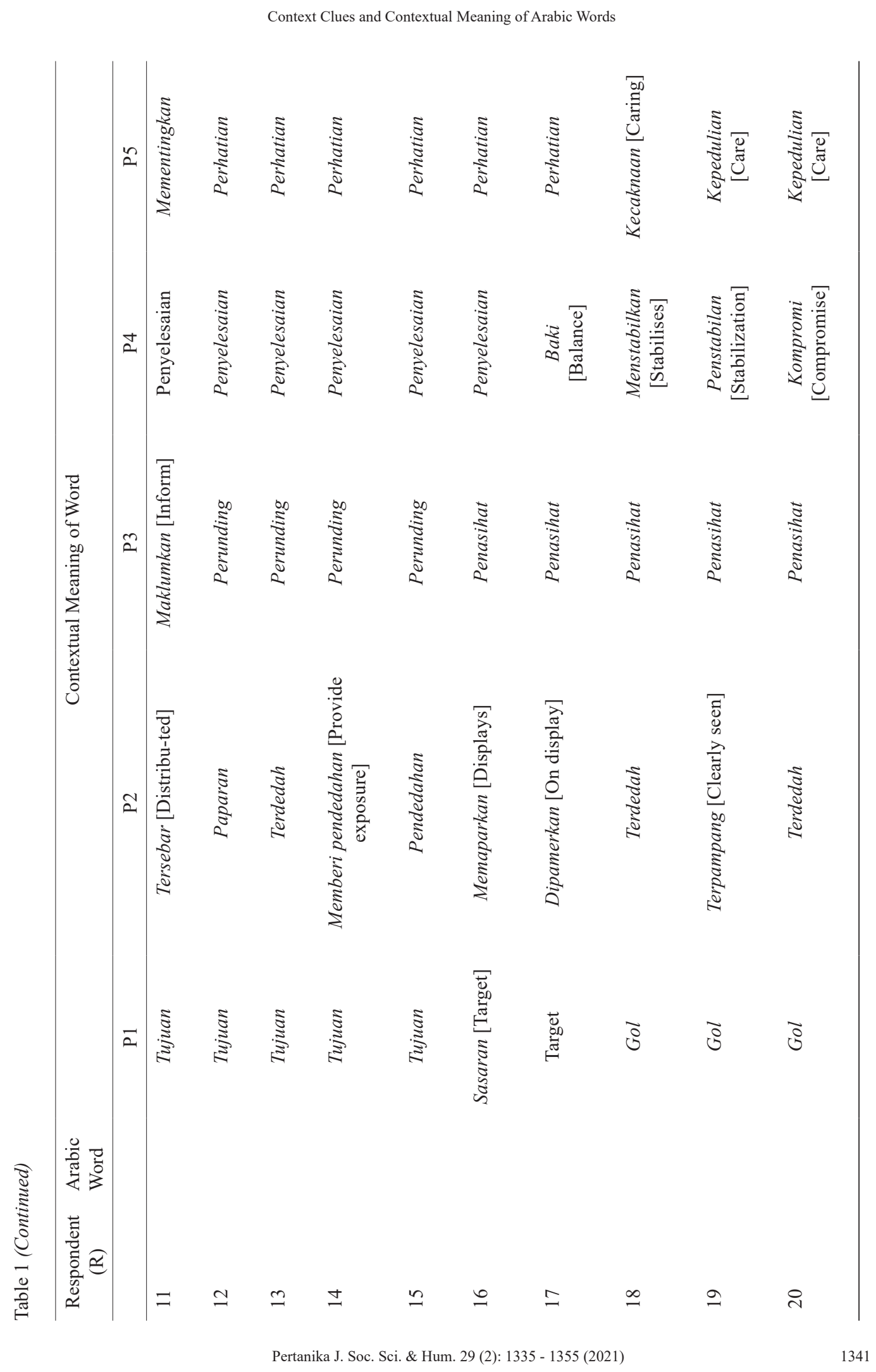


For P3, most gave the contextual meaning "penasihat" [adviser] as stated by R01, R02, R03, R04, R05, R07, R16, R17, R18, R19 and R20. Whereas R10 gave the same meaning in the English language. The adviser in this text refers to the person advising the president of Israel, which is Donald Trump. The other respondents, R09, R12, R13, R14 and R15 gave the meaning for " "مُسنتَنََّار" as "perunding" [consultant]. One respondent, R08, determined it as "presiden" [president] which also means a leader or one with authority to give advice. R11 responded in the form of a verb "maklumkan" [inform] which refers to the duty of an adviser in the text. Only one respondent, R06 gave a different contextual meaning, which is "menantu" [daughter/son in law]. As for P4, the contextual meaning determined differed. Frequently given was "penyelesaian" [solution] as stated by R08, R09, R10, R11, R12, R13, R14, R15 and R16. R02 gave the same meaning with different affixes which is "menyelesaikan" [to solve]. Three respondents gave close meanings, they were R01; "mendapat kenaikan" [obtain increase], R06; "mencecah" [reaches], and R07; "kenaikan" [increase]. These three meanings revolve around the price increase of crude oil stated in the original text. Next, R03, R04 and R05 defined the word "تشَنْوِيَِة" as "purata" [average] which is the most accurate meaning in the context of the actual sentence. R18 and R19 provided "menstabilkan" [stabilize] and "penstabilan" [stabilization]. Both mean the same with different affixes, which is a situation that does not change or fluctuate; that meaning can be connected to the price of crude oil. Only respondents R17 and R20 determined a different contextual meaning, which is "baki" [balance] and "kompromi" [compromise].

The respondents were able to provide the accurate contextual meaning for P5 because the meaning determined was almost the same. The meaning provided most is "perhatian" [attention] as stated by R01, R06, R12, R13, R14, R15, R16 and R17. The next is "kepentingan" [importance] as provided by R02, R07, R08 and R10. Both these words have the same meaning. R09 and R11 also gave the meaning from the base word "penting" [important] with different affixes which is "mementingkan" [stress importance]. Whereas R03 and R05

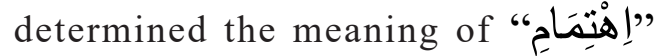
as "menitikberatkan" [emphasizes] and "memfokuskan" [focuses]. These three verbs mean the same, but the original word in the text is in the form of a noun (isim), not a verb (f'il). R04 responded with "fokus" [focus] which shows a noun, suitable with the placement of the original word in the Arabic text. R19 and R20 defined P5 as "kepedulian" [care] which is a synonym for "perhatian". Similarly, the contextual meaning as stated by R18, "kecaknaan" [caring] which comes from the word "cakna" [care] which is about caring and attention.

\section{Analysis of Discourse Practice Dimension}

This second dimension will focus on how 
the student interprets the meaning of the Arabic word by using the context clue found in the discourse or text. Fairclough explains that the interpretation procedure in this dimension is divided into two parts, which are interpretation of text and context. Therefore, we connected the context clue with the determination of the correct contextual meaning of the word by the respondent as shown in Table 2.

In any dictionary, the word "هَدَتُ" (P1) means purpose or objective. However, in sports, it means scoring a goal, as understood by the respondent. There are several words, phrases or sentences found in the text which became context clues for the respondent to determine the contextual meaning of this word. As stated by R08, R09, R12, R14, R17 and R19 they connected the word found after it to obtain the true contextual meaning. The word

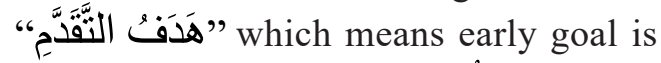

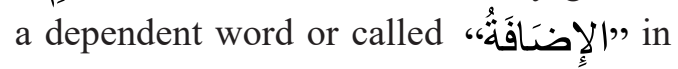
Arabic language grammar, which are two nouns combined and depend on one another

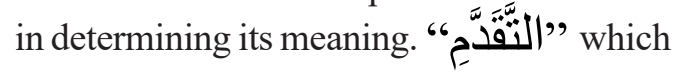
means advance was seen as the clue for the respondent to match its meaning with goal. R08, R10, R13, R16 and R20 chose

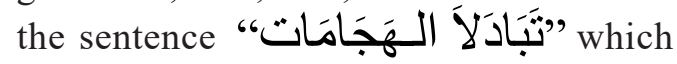
means "exchanging attacks" as context clue. This showed that the respondent is capable of understanding the situational context in the sentence and connects it in the process of determining the meaning of the word after it which is "هَدَفنُ" " In the context of football, exchange of attacks between two teams is solely for the purpose of scoring a goal, as the text narrates that the Chelsea and Manchester United teams exchanged attacks to obtain the early goal. Five respondents, R01, R03, R04, R05 and R06 chose the sentence found before P1

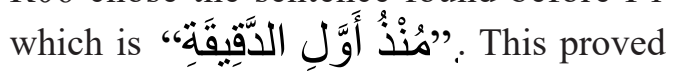
that the respondent is able to find the connection between the sentences "since the first minute" with "early goal" in the context of football news. Sentences found in the text play a crucial role in helping the reader find the clue or context clue in determining the meaning of an unclear or unknown word. According to R15 and R18, the word "الــُبَارَ الِ، which means "match" became the context clue for understanding the meaning of "scoring a goal" in the text. The

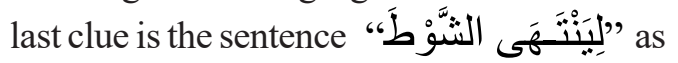
stated by R02 and R11 which means "to end the first minute". The respondent was able to understand the contextual meaning of P1 by referring to the sentence after the word being tested in the original text.

For P2 which is the verb "تََعَرَّض", the respondents provided context clues according to their individual understanding. The context clue most frequently chosen by R03, R04, R05, R08, R09, R12 and R17 was the sentence

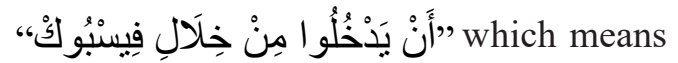
"logging in through Facebook". This sentence appears after the word "تَعَرَّضَ" that can become a declarative sentence which explains about certain webpages that request the user to sign in using their Facebook page to save time while accessing certain user information. For R01, R02 and R07, the phrase "'فِي الْأَحْيَانِ" meaning "sometimes", became a clue to understand the contextual 
Table 2

Context clue used by respondent

\begin{tabular}{|c|c|c|}
\hline Arabic Word $(\mathrm{P})$ & Respondent (R) & Context Clue \\
\hline \multirow[t]{5}{*}{ Pَدَفُ P1 } & $08,09,12,14,17,19$ & 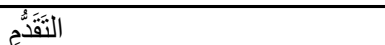 \\
\hline & $08,10,13,16,20$ & تَبَادَلاَ الـهَجَامَات \\
\hline & 15,18 & الـُبَبَرَاةِ \\
\hline & $01,03,04,05,06$ & مُنْذُ أَوَلِ دَقِيقَةِة \\
\hline & 02,11 & لِِينتنَهَى الثنَّوُْطَ \\
\hline \multirow[t]{6}{*}{ P2 ت تَعَََّضن P2 } & $03,04,05,08,09,12,17$ & أَنْ يَخْخُوُو امِنْ خِلَلِلِ فِيسنبُوكُ \\
\hline & $01,02,07$ & 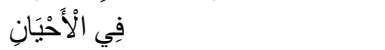 \\
\hline & $10,16,20$ & مُحْْنَََ يَاتِتهَا \\
\hline & $14,15,19$ & فِِيسنبُو كَّْ \\
\hline & 06,13 & عَلْيْهُ \\
\hline & 11,18 & 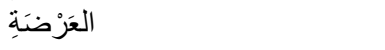 \\
\hline \multirow[t]{4}{*}{ 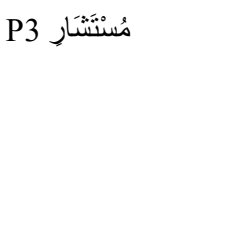 } & $\begin{array}{l}02,03,04,05,06,08,10,12,13 \\
14,15,16,17\end{array}$ & صنهُرُ الرََّئيسِ ترَمْب \\
\hline & $01,07,19,20$ & جَارِيدُ كُوشَنْرَ \\
\hline & 11,18 & 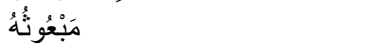 \\
\hline & 09 & Person dealing with a party \\
\hline \multirow[t]{6}{*}{ 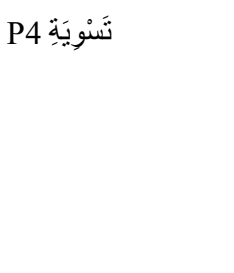 } & $02,03,05,07,08,09$ & 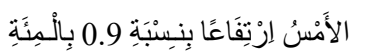 \\
\hline & $01,06,17$ & إِرْتِفَاعًا \\
\hline & 04 & 0.90 \\
\hline & $10,12,13,14,15,16,20$ & وَحَقَّقَ النَّفَطُ الََْامُ \\
\hline & 18,19 & لِِيَنَتَأْنِبِ صـُعُو دُهُ \\
\hline & 11 & عِنْدَ \\
\hline \multirow[t]{5}{*}{ إِهْتِمَاحِ P5 } & $\begin{array}{l}01,02,03,04,05,08,11,12,13 \\
14,15,16,17\end{array}$ & أَجْيَالُ الـجَدِيدةٍة \\
\hline & 19,20 & لَا نَفَقَدَ \\
\hline & 07,18 & مَسنْحُ التُشرَاثِ \\
\hline & 06 & $\begin{array}{l}\text { New generation must be } \\
\text { sensitive }\end{array}$ \\
\hline & 09,10 & Heard before and often used \\
\hline
\end{tabular}


meaning of " "نَعَرَّضنَ" which shows that not all webpages have this request. Several respondents, R10, R16 and R20 determined

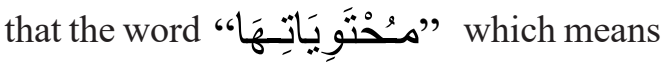
"its contents" refers to user information. As understood by these respondents, by registering to enter the webpage using Facebook, the user will then automatically disclose their personal information to that webpage. There were also respondents, R14, R15 and R19 who chose the word

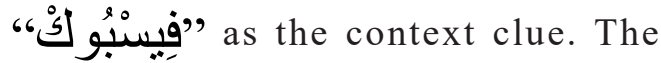
word is after P2 and became the clue to understand the meaning of "تَعَرَّضَ" that is connected to Facebook. Whereas respondents R06 and R13 viewed the word "عَلَبْهِْْ " that appears immediately after P2 as the context clue for understanding said meaning. The personal pronoun or dhamir "ه on the word refers to the user of the webpage that is meant in the actual text. R11 and R18 have mentioned the base word for

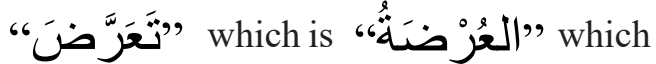
means "target" as the context clue. Although the meaning is not in line with the contextual meaning required, the respondent is able to understand the meaning of $\mathrm{P} 2$ in a manner which is out of context but unable to adapt to the context of the actual sentence. The word early on in the sentence, "تَحَرََّضن", became the clue that explained about certain webpages that required the user to set up an account and sometimes the user is requested to log in using their Facebook page which could expose their personal information.

The next word, P3, was “" "مُسْنَشَارَ" which means "adviser", that refers to the right-hand man to President Trump. According to R02, R03, R04, R05, R06, R08, R10, R12, R13, R14, R15, R16 and R17 the phrase "صَنْرُ الرَّئيسِ ترَمْنب which means President Trump became the context clue to determine the meaning of " مُسْتَنَشَارِ An adviser is an individual or a group that has the skills in an area of expertise which is used for a certain purpose by the organisation or company. This differed from R01, R07, R19 and R20 who referred to the name of the adviser, ” جَارِيذ كُوشْنَرْهُ" as the context clue. Jared Kushner is an individual who holds the position of adviser to President Trump. The next context clue mentioned by R11 and R 18

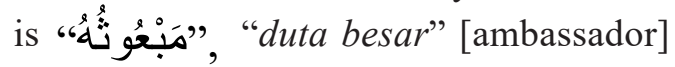
which means "wakil yg dilantik secara sah atau dihantar (oleh kerajaan, pertubuhan, firma) ke negara asing" [a representative appointed legally or sent (by the government, association, firm) to a foreign country] (Kamus Dewan, 2005). The respondents chose the word found after the word tested to understand its contextual meaning. Both the adviser and the ambassador are responsible in matters relating to diplomatic relations and are the right-hand persons to President Trump. R09 defined it as "person dealing with a party" and can also be referred to as an adviser in news text. This showed that the respondent was able to use existing knowledge to understand the contextual meaning of the tested text.

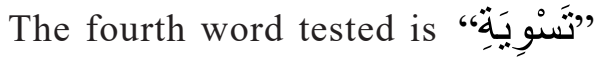
which means "average" in the original news text. Several respondents, R02, R03, R05, R07, R08 and R09 chose the 
sentence after the word tested which

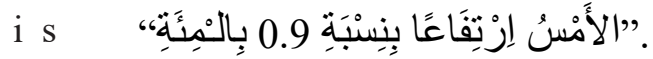
This sentence explains the overnight price increase of 0.9 percent. This declarative sentence became the clue for the respondent to understand the contextual meaning of P4. For R01, R06 and R17, the context

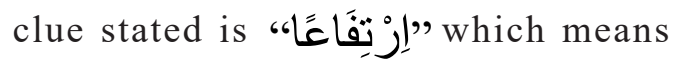
"increase", refers to the price of crude oil. Whereas R04 chose the value of the increase, which is "0.9بِّف 0.9 percent. For R10, R12, R13, R14, R15, R16 and R20, the sentence that became the context clue

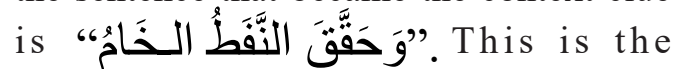
beginning of the sentence that mentions the increase of crude oil in America and gave a clue to the respondent for the contextual meaning of P4. R18 and R19 stated that

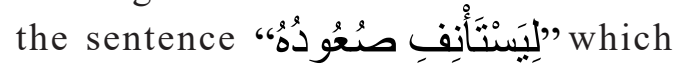
means "to continue its increase" as the context clue. This sentence also appears

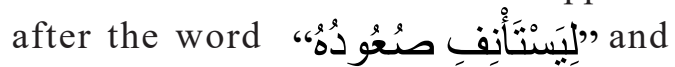
the respondents were able to connect this declarative sentence to determine its meaning. For R11, it was the word "عَنْدَ" meaning "at", that refers to the time the increase in crude oil occurred, which was yesterday.

For the final word tested, different context clues were given to understand

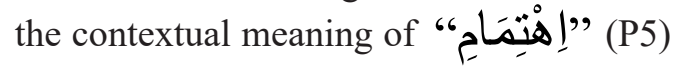
which means "attention" in the news text. Among the context clues that assisted the

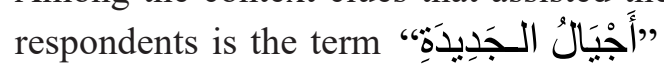
as stated by R01, R02, R03, R04, R05, R08, R11, R12, R13, R14, R15, R16 and $\mathrm{R} 17$. This term means "new generation" which no longer value cultural activities that have been handed down for generations but instead value more modern activities. Whereas R19 and R20 chose the sentence

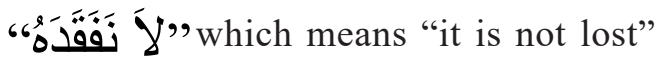
which refers to cultural activity. This sentence can become the context clue by referring to the preceding sentence where the Minister of Culture recommends for more programmes focusing on cultural heritage so that it is not lost with time. R07 and R18 viewed that the context clue is the sentence

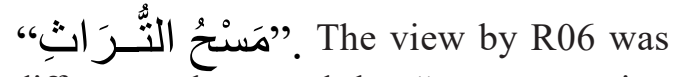
different, who stated that "new generation must be sensitive" as the context clue where this sentence refers to the sentence after the word tested. As for R09 and R10, they only used their personal experience as context clue as they have heard the word before and used it often in learning the Arabic language.

Based on this, we can conclude that the respondent is able to use the words and sentences found in the text to become context clues for understanding the contextual meaning of Arabic words tested. Respondents need not refer to the dictionary as the clue or guide found in the text helps extensively in determining the meaning which is unclear or unknown. Since this study observes the extent context clues can assist the respondent in determining the contextual meaning of the Arabic word, we did not evaluate the grammatical correctness of the answers.

\section{Analysis of Social Practice Dimension}

This third dimension is the final analysis in the framework and involves the process of critical explanation. We will explain 
the student's understanding process in determining the contextual meaning of the Arabic word based on the context clues found in the five news texts. The student goes through the process of looking for context clues, interpreting as well as determining whether the meaning of the word is suited to the context of the sentence. We will also explain the importance of the context clue in assisting in the search for the meaning of the word contextually. The interview method was used to more clearly understand the process where the student interacts with the text and the context clue in the Arabic language.

\section{Methods of Obtaining Context Clue in the}

Text. We would like to understand the ways the respondent looks for or obtains context clue in the text. Context clue can be referred based on a word, term, phrase, sentence and so on to assist the respondent to obtain the clue to understand the meaning of a word. The findings of the research by Kanatlar (1995), show that predicting the meaning of the word through context clue is the most popular strategy among students.

Referring to the Word Before and After. We found that obtaining the context clue by referring to the word before and after is the technique most used by the respondents. The word or sentence before and after the Arabic word tested plays a vital role in assisting the student understand the meaning required. The word or sentence that becomes the context clue can be categorised as a synonym, definition, term that is often used in daily life, a declarative sentence and so on. The before and after word and sentence then becomes a clue and connected to the context and meaning of the sentence that is to be conveyed.

(R01) "Knowing the meaning of the word before and after the keyword, and then matching the meaning of the word with the narration context in the text"

(R03) "By looking for the meaning of the word which is not understood and then identifying the sentence before and after said word"

(R04) "I will look for the word that has a connection to it or by looking or reading the sentence before or after it"

(R10) "Seeing or referring to the sentence before and after a meaning to understand the purpose of the essay"

(R17) "By understanding the sentence before and the sentence after it. If not able to, I will try to adapt according to the title of the text given"

(R20) "Refer to other words present before or after"

Besides referring to the word or sentence before and after, respondents also tried to find the connection between the sentence and the word with the Arabic word tested as stated below.

(R05) "Refer to a related sentence with the same meaning either before or after the relevant sentence"

(R16) "Looking at the related word or sentence that brings meaning to the said word" 
There were also respondents who referred to other words which explain the word being tested.

(R07) "Look for the context clue that explains that word or the word refers to a context clue"

Understanding the Context of the Sentence.

The context of a sentence plays an important role in determining the meaning of a word as the meaning changes when placed in a certain context. The research findings by Çetinaveı (2014) show that a sentence rich with context enables the student to correctly guess the meaning of the word. Respondents also used the context of the sentence to find the clue when trying to understand the meaning of the Arabic word tested.

(R11) "Looking at the context of the sentence and the important content of the text"

(R19) "By looking at the context similarities being discussed in the text."

\section{Understanding the Meaning of the Word.}

To understand the meaning and message conveyed by a text, mastery of the vocabulary and understanding the meaning of the word are important. There were respondents who obtained the context clue by understanding the meaning of either the word being tested or the word before or after it.

(R09) "Try to understand the title and try to understand several words or sentences in the quotation"

(R12) "Understand the meaning of the word or text"

Some respondents referred to the words that they already know the meaning to assist.
(R02) "Look for the word already understood and the word that can help me know the meaning of the word"

However, some respondents chose to directly understand the meaning of the context clue in the text as stated.

(R08) "Understand the context clue in the text"

Understanding Overall Text. Mastery of vocabulary enables the reader to understand the implicit and inferred in the text. According to Bromley (2000), vocabulary is presumed the main contributor to understanding, fluency, and attainment in a text. In this study, some respondents understood the text as a whole to obtain the context clue to determine the contextual meaning of the Arabic word tested.

(R14) "Try to understand the overall text"

(R18) "I will read the entire text and understand the gist"

Other Alternatives. Other alternatives used by the respondents to obtain the context clue included using the Google Translate application.

(R06) "I will look for the meaning of the word from Google Translate"

The respondent not only obtained the answer instantly, but also obtained a clue or context clue based on the translation provided.

Alternatively, there were those who discussed with friends to look for the context clue in the text. 
(R13) "Asking friends and try to invite them to discuss about what the excerpt is trying to say or convey"

Yet another alternative used by the respondent is by looking for the subject and predicate or mubtada' wal khabar in a sentence.

(R15) 'I look for mubtada' and khabar in a sentence"

\section{Importance of Context Clues}

Based on the study conducted, context clues can help the respondent in determining the contextual meaning of the Arabic word in the text. Although given the option to refer to the dictionary, respondents were able to determine the meaning of said word by only referring to the word and sentence found in the text. The view of Hibbard (2009) states that one way to support the development of vocabulary and assist the reader is by identifying new words and mastering the search for meaning by using context clues. The importance of context clues presented by the respondents includes enabling clear understanding of the meaning of the word, knowing the different meanings of a word, able to master meaning based on context and able to easily understand the entire text.

\section{Clearly Understand the Meaning of the}

Word. Besides referring to a dictionary, the respondent can use the context clue to help know and understand the meaning of an Arabic word clearly as stated below.

(R03) "Context clue is very important for understanding the meaning of a word as it helps to facilitate if there is no dictionary or any reference. For example, when answering a question during an examination"

(R16) "I am of the view that context clues are very important in determining the meaning of a word especially when there is no dictionary. This way is very helpful in understanding the word or sentence that is not known"

Using the context clue also saves time when looking for the meaning of the word without having to refer to other sources.

(R14) "In my view, context clue is very important in determining the meaning of a word as it is easy for me to understand a word more accurately and quickly"

(R02) "Important to make it easy for me to understand the text quickly without referring to any online and offline dictionaries."

Some students assumed that context clues are extremely important in determining the meaning of a word or sentence, as they were then able to understand the intended message of the entire text as stated by the respondent:

(R06) "Important, because if one does not understand the meaning of the word, he will change the meaning of the Arabic text"

Nevertheless, there were views that if one is unable to understand the meaning of the context clue accurately and correctly, it can lead to a meaning that is inaccurate and incorrect.

(R08) "Very important because if we misunderstand the meaning of the context clue then the meaning of the word is also wrong." 
(R13) "By understanding the context clue, I can guess the meaning of a word and sometimes not accurately"

Know the Various Meanings of the Arabic Word According to Context. When communicating in Arabic language text, the reader is unable to determine the meaning of a word without looking at the context of the sentence in the text. This is because it changes according to the situational context in a specific condition. Most students were of the opinion that context clues are particularly important in understanding the meaning of an Arabic word as most words have multiple meanings.

(R09) "Indispensable because one word or sentence has many meanings."

(R15) "Context clue in determining the meaning of a word is very important because the Arabic language is a unique language where one word can have various meanings but depending on the context of that sentence"

(R12) "Essential because the meaning of the word is sometimes different according to the text"

(R10) "Important, because there are various meanings in one word or sentence"

(R01) "Context clue is very important to determine the meaning of something because without context clue, the meaning of that word can change or is different and can change the meaning of the text"

(R18) "Important in understanding what is being narrated and discussed in the text. This is because every text has a different context. So, it is very important to determine the context to determine the meaning of a word"

Besides being able to adapt the variability of meaning of the Arabic words with the context of the sentence, the students were also of the view that context clues can provide understanding so that the meaning chosen does not affect the true meaning of the sentence and can determine the accurate contextual meaning.

(R17) "It is very important because a word can change meaning according to the context of the sentence. It will become different if literally translated. So, having the context clue, it will help me to adapt the meaning with the context of the sentence"

(R20) "The importance of the context clue in determining the meaning of a word because incomprehension of context can affect the accuracy of translating the meaning and may be different from the intended true meaning"

(R07) "Context clue is very important because if we only translate a word without referring to the context clue. Most probably will be wrong in translating that word"

\section{Convey the Meaning of the Entire Text.}

The main component when reading an Arabic text is understanding the entire text. When one is able to accurately know the meaning of the word and sentence in the text, then one will easily understand the meaning of the entire text. Students recognised that using context clues helps them understand the meaning of the word based on the context of the sentence and 
subsequently to master understanding the entire text.

(R11) "Able to convey meaning to the reader"

(R19) "Context clue is important in determining the direction of the intended text"

(R04) "Context clue is very important for me because it is easy for me to understand the entire text when I face the problem of not having a dictionary"

(R05) "For me the context clue is very important because it makes it easier for me to understand the sentence of the entire text"

Based on the analysis of the social practice dimension, we can conclude that the student is able to benefit from the context clues found in the text to determine the meaning of the Arabic word tested. Several methods were practiced in obtaining the context clue, including referring to the word before and after as well as understanding the context of the sentence. Other alternatives included using the Google Translate application, discussions with friends and looking for the mubtada' wal khabar in the sentence.

\section{CONCLUSION}

This study is an attempt to understand the relation between context clues and contextual meaning of Arabic words in order to help learners understand the real message behind a text. Most students pursuing the Arabic course or subject were only able to understand the meaning of the word lexically without considering the context features in a sentence or text. Therefore, context plays a very important role in learning Arabic language (Abd Rahman \& Abdul Jabar, 2014). The learning and teaching techniques for the Arabic language should vary and not focused merely on syntax and morphology. This is important to inculcate interest as well as improve the mastery and understanding of the student, including introducing the context clue technique.

The use of context clues plays a role in assisting the student determine the meaning of an Arabic word accurately and correctly based on the context of the sentence and the text as a whole. This method is still not fully practised in the study of Arabic language in Malaysia as most students still rely on dictionaries or online translation applications. We have high hopes that this study will open the eyes of the educators as well as other researchers of the Arabic language to increase the effort to benefit from context clues in the learning session whether in or outside the classroom. Improvement in terms of creativity and the method of using this context clue can be studied in greater detail until such time it is able to have a positive impact on the development of Arabic language in Malaysia.

\section{ACKNOWLEDGMENT}

We would like to acknowledge Universiti Putra Malaysia for financial assistance under the UPM Putra Grant (GP/2017/9560300). 


\section{REFERENCES}

Abd Rahman, M. Z. \& Abdul Jabar, M. A. (2014). Pengaruh budaya tempatan dalam pembelajaran bahasa Arab di sekolah [Influence of local culture in learning of Arabic language in school]. ElSevier Procedia-Social and Behavioral Sciences, 134, 373-381. https://doi.org/10.1016/j. sbspro.2014.04.259

Abdul Jabar, M. A. (2011). Analisis wacana Arab [Arabic discourse analysis]. Dewan Bahasa dan Pustaka.

Allen, L. (1998). An integrated strategies approach: Making word identification instruction work for beginning readers. The Reading Teacher, 52(3), 254-268.

Baharum, A. S., \& Samah, R. (2015). Persepsi pelajar universiti terhadap kesalahan bahasa Arab, faktor penyumbang dan implikasi [The perception of university students towards errors in the Arabic language, contributing factors and implications]. Sains Humanika, 6(1), 35-42. https://doi. org/10.11113/sh.v6n1.595

Benjamin, A., \& Crow, J. T. (2009). Vocabulary at the center. Eye on Education.

Bromley, G. (2000). Environmental games to teach concepts and issues. School Science Review, 82(298), 39-46.

Carver, R. P. (1994). Percentage of unknown vocabulary words in text as a function of the relative difficulty of the text: Implications for instruction. Journal of Literacy Research, 26(4), 413-437. https://doi.org/10.1080/10862969409547861

Çetinavc1, B. M. (2014). Contextual factors in guessing word meaning from context in a foreign language. Procedia-Social and Behavioral Sciences, 116, 2670-2674. https:// doi.org/10.1016/j.sbspro.2014.01.633

Dash, N. S. (2008). Context and contextual word meaning. SKASE Journal of Theoretical Linguistic, 5(2), 21-31.
Fairclough, N. (1989). Language and power. Longman Group Limited.

Hall, E. T. (1974). Beyond culture. Doubleday.

Harris, T. L., \& Hodges, R. E. (1995). The literacy dictionary: The vocabulary of reading and writing. International Reading Association.

Hasmam, A. (2012). Pengalaman guru bahasa Arab menggunakan teks yang berbeza jenis dalam pengajaran kemahiran mendengar peringkat permulaan [Experience of Arabic language teachers using different types of texts in teaching beginner level listening skills]. Prosiding Persidangan Kebangsaan Pengajaran dan Pembelajaran Bahasa Arab 2012 (PKEBAR'12; pp. 15-33). Unit Bahasa Arab, Fakulti Pengajian Islam, Universiti Kebangsaan Malaysia.

Hasmam, A., Nik Yusuf, N. M. R., Lubis, M. A., \& Sjahrony, A. (2017). Amalan strategi pemahaman makna kosa kata bahasa Arab berasaskan konteks penggunaan dalam pengajaran guru cemerlang bahasa Arab [Practice of the strategy for understanding the meaning of Arabic language vocabulary based on the context of use in teaching by excellent teachers of Arabic language]. ASEAN Comparative Education Research Journal on Islam and Civilization (ACER-J), 1(2), 53-66. http://spaj.ukm.my/acerj/ index.php/acer-j/article/view/27

Hibbard, R. (2009). The effects of context clue instruction on finding an unknown word. http:// reflectivepractitioner.pbworks.com/f/capstone3. pdf

Hsueh-chao, M., \& Nation, P. (2000). Unknown vocabulary density and reading comprehension. Reading in a Foreign Language, 13(1), 403-430. https://doi.org/10.26686/wgtn.12560354.v1

Kamus Dewan Edisi Keempat [Dewan Dictionary Fourth Edition]. (2005). Dewan Bahasa dan Pustaka.

Kanatlar, M. (1995). Guessing words in context strategies used by beginning and upper- 
intermediate learners [Unpublished master's thesis]. Bilkent University.

Mahmoud, S. S. (2016). How contextual clues and nonsense words facilitate reading comprehension. Journal of Language Teaching and Research, 7(1), 88-98. https://doi.org/10.17507/jltr.0701.10

Mansor, S., \& Abdul Jabar, M. A. (2019). Penggunaan petunjuk konteks dalam menentukan makna kontekstual perkataan Arab dalam teks berita politik [The use of context clues in determining contextual meaning of Arabic words in political news text]. The Journal of Humanities and Social Sciences, 6(2), 195-206.
Requejo, M. P. (2007). The role of context in word meaning construction: A case study. International Journal of English Studies, 7(1), 169-173. https://doi.org/10.6018/ijes.7.1.48991

Yuen, J. (2009). Context clue detectives: Empowering students with a self-learning device through the teaching of context clues [Unpublished master's thesis]. University of California. 


\section{Annexes}

\section{Sports News Text}

\section{تشتبلسي بتأهل إلى نهائي كأس الاتحاد الإنجليزي}

انتزع الفريق تُشيلسي اليوم الأحد بطاقة التأهل إلى المبار اة النهائية لبطولة كأس الاتحاد اللإنجليزي لكرة القدم. وتغلب تشيليلي

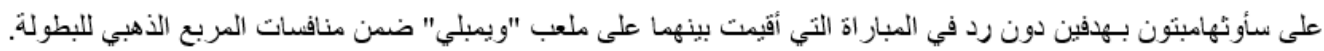

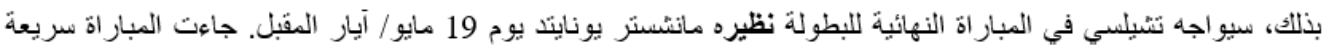
وحماسية من جانب لاعبي الفريقين، تبادلا الهجامات منذ أول دقيقة في رحلة بحت عن هاف الثقلم، ونتو الت الفرص الضائعة من

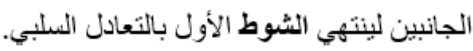

http://alrai.com/article/10433992 (22.4.2018)

\section{Technology News Text}

\section{خطأ كبير يفعله كثيرون من مستخدمي فيسبو ك (T2)}

نبه باحثون رقميون من جامعة برينسنون، مؤخر ا، إلى أن تسجيل الدخول لبعض المو اقع الإلكترونية بحسابات فيبسوك، و هو

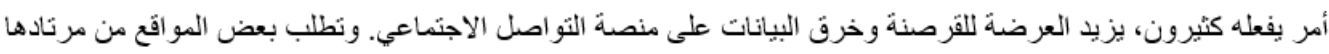

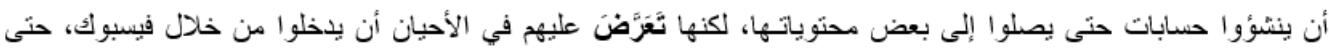

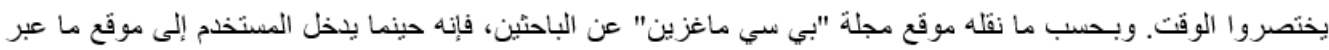

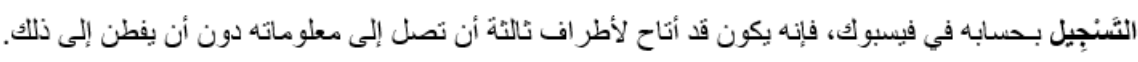
http://alrai.com/article/10434248/ (24.4.2018)

\section{Political News Text}

\section{و) وانُنطن تستعد لنشر (صفقة القرن) بعد رمضان}

كتف صحيفة (ايديعوت أحرونوت) الاسر ائيلية، امس السبت، ان إدارة الرئيس الأمبركي دونالد ترمب، تستعد لنشر خطته

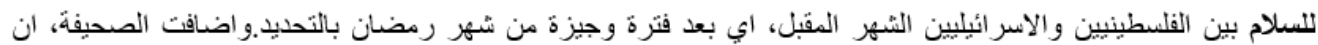

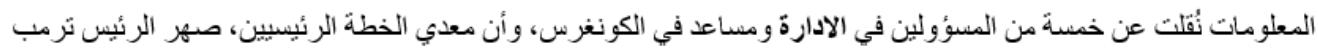

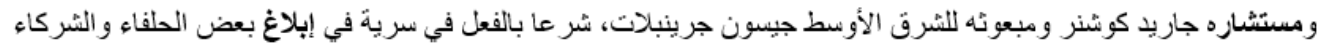

http://alrai.com/article/10437481/ (20.5.2018) 


\section{Economic News Text}

\section{ارتفاع أسعار النفط}

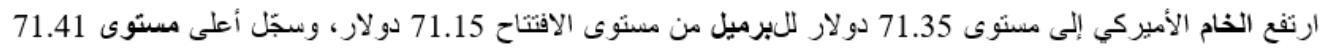

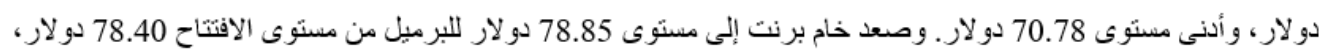

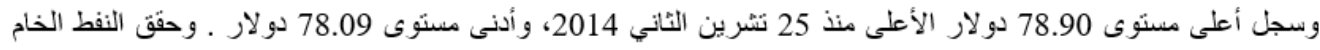

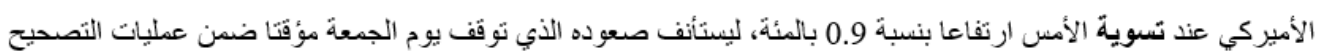

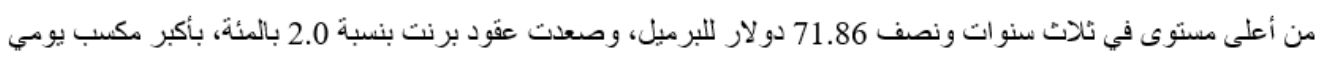
منذ 18 نبسان.

http://alrai.com/article/10436962/(15.5.2018)

\section{Social News Text}

\section{وزير الثقافة بكزم الثناعر الهقيش}

أكد وزير الثقافة نبيه شقم على أهمية إبر از تراث البادية الأردنية بكافة أشكاله من خلال النشاطات الثقافية التي تؤكد على اصلأله،

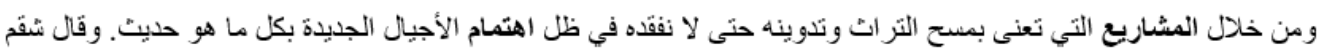

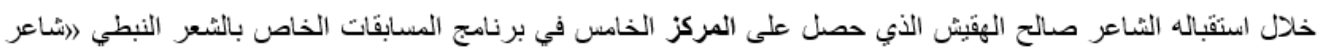

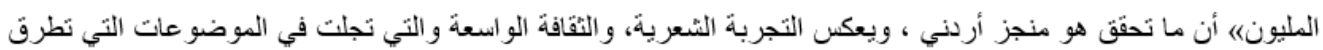
إليها (الهقبش) في قصائده.

http://alrai.com/article/10437022/ (16.5.2018) 
